\title{
Axonal Interactions Regulate Schwann Cell Apoptosis in Developing Peripheral Nerve: Neuregulin Receptors and the Role of Neuregulins
}

\author{
Judith B. Grinspan, ${ }^{1}$ Mark A. Marchionni, ${ }^{2}$ Matthew Reeves, ${ }^{1}$ Markella Coulaloglou, ${ }^{1}$ and Steven S. Scherer ${ }^{3}$ \\ ${ }^{1}$ Division of Neurological Research, Children's Hospital of Philadelphia, Philadelphia, Pennsylvania 19104, 2Cambridge \\ NeuroScience, Cambridge, Massachusetts 02139, and 'Department of Neurology, The University of Pennsylvania \\ Medical Center, Philadelphia, Pennsylvania 19104-6146
}

Programmed cell death during development resulting from the lack of appropriate survival factors has been demonstrated in both neurons and oligodendrocytes and occurs mostly in the form of apoptosis. We now demonstrate that Schwann cells in the rat sciatic nerve undergo apoptosis during early postnatal development and that the amount of apoptosis is markedly increased by axotomy. The apoptotic Schwann cells express the low-affinity nerve growth factor receptor but not myelinrelated proteins, indicating that they are in the premyelinating state. Apoptosis resulting from normal development or from axotomy can be inhibited markedly by exogenous neuregulin. Consistent with this, the neuregulin receptor components erbB2 and erbB3 are expressed and phosphorylated in developing sciatic nerve. These data suggest that Schwann cell number in developing peripheral nerve is regulated by apoptosis through competition for axonally derived neuregulin.

Key words: myelin; axon-Schwann cell interactions; S-100; erbB2; neu; erbB3; cell death; glia
In the developing CNS and peripheral nervous system (PNS), the differentiation of neurons is accompanied by a large amount of cell loss in the form of programmed cell death. Cells that die from programmed cell death are most commonly eliminated by apoptosis, a process characterized by nuclear fragmentation in an otherwise intact cell. Initially, the chromatin condenses, the nucleolus disintegrates, and the nucleus shrinks; eventually, the nucleus and cytoplasm bud and separate into multiple, membrane-bound apoptotic bodies that are phagocytosed by macrophages or surrounding cells (Kerr et al., 1972; Arends et al., 1990; Sen, 1992; Wijsman et al., 1993). These processes have been studied extensively in developing PNS neurons, whose survival depends on trophic factors that are provided by their targets (Purves and Lichtman, 1985; Korsching, 1993; Snider, 1994). Neuronal cell death results from competition for limited amounts of growth factors and may serve various purposes, such as eliminating inappropriate connections or matching the number of neurons to the size of their target (Cowan et al., 1984).

Schwann cells, the sole glial cell of the PNS, also die during development. The earliest Schwann cells are known as precursors and have been characterized extensively in vitro by Jessen and Mirsky and their colleagues (Jessen and Mirsky, 1992; Jessen et al., 1994; Gavrilovic et al., 1995; Stewart et al., 1995). Precursors

\footnotetext{
Received May 24, 1996; revised July 8, 1996; accepted July 15, 1996.
}

This work was supported by grants from National Institutes of Health (NS08075, NS34528, and NS01565 to S.S.S.; NS01793 to J.B.G.) and by the National Multiple Sclerosis Society (RG 2153-B3 to J.B.G.). We thank Shelly Whyatt, Kristen Cronin, and Tracey Oliver for technical assistance; Drs. Eugene Johnson, Peter Brophy, Kermit Carraway, and Cary Lai for their generous gifts of antibodies against NGFR/p75, periaxin, erbB3, and erbB4, respectively; Yunhee Kim Kwon and Charles Stiles for advice on methods for homogenization of frozen tissues that preserve phosphorylated tyrosines; Maria Pita for artwork; and Lynn Rutkowski and David Pleasure for their critical reading of this manuscript.

Correspondence should be addressed to Dr. Judith B. Grinspan, Division of Neurological Research, Children's Hospital of Philadelphia, 3517 Civic Center Boulevard, Philadelphia, PA 19104.

Copyright (C) 1996 Society for Neuroscience $0270-6474 / 96 / 166107-12 \$ 05.00 / 0$ appear at approximately embryonic day 14 (E14), but do not express the markers of more mature Schwann cells, S100 $\beta$, O4, $\mathrm{O} 1$, and galactocerebroside, which are acquired later (beginning at E17). Schwann cell precursors, but not Schwann cells, are trophically dependent on basic fibroblast growth factor (bFGF), insulin-like growth factor-1 (IGF-1), or neuregulins for their survival in culture.

Neuregulins [also known as glial growth factors (GGF), neu differentiation factor, heregulins, and ARIA] are a group of peptide growth factors expressed by embryonic neurons (Marchionni et al., 1993) and mesenchymal cells (Meyer and Birchmeier, 1994). The forms of neuregulins that correspond to the GGF were identified originally as an activity from pituitary glands that stimulated proliferation of astrocytes and Schwann cells (Brockes et al., 1980; Lemke and Brockes, 1984; Lemke, 1990). Subsequent purification of the peptides and cloning of the neuregulin gene demonstrated that alternative splicing of the neuregulin gene generates multiple isoforms, including ones that are predicted to be intracellular, transmembrane, or secreted (Marchionni et al., 1993; Wen et al., 1994). The importance and activities of the various isoforms have just begun to be elucidated, but the so-called $\alpha$ and $\beta$ isoforms, created by the alternative splicing of an epidermal growth factor-like domain, differ in their potency as mitogens and survival factors for Schwann cell precursors (Dong et al., 1995). The major isoform made by sensory and motor neurons has been described recently (Ho et al., 1995), but its relative potency as compared with the other neuregulin isoforms has yet to be established. Motor and sensory neurons probably express and axonally transport neuregulins beginning in early embryonic stages (Marchionni et al., 1993; Chen et al., 1994; Corfas et al., 1995; Sandrock et al., 1995), making it plausible that axonally derived neuregulins are continuously available to Schwann cells from the earliest times in their development.

In this paper, we report that Schwann cells are subjected to programmed cell death in vivo during the first two postnatal 
Table 1. Neuregulin prevents apoptosis in P1 sciatic nerves axotomized for $1 \mathrm{~d}$

$\%$ TUNEL-positive nuclei

\begin{tabular}{lll}
\cline { 2 - 3 } Treatment & $\begin{array}{l}\text { Transected } \\
\text { (left) side }\end{array}$ & $\begin{array}{l}\text { Untransected } \\
\text { (right) side }\end{array}$ \\
\hline Transection, no neuregulin & $9.44 \% \pm 3.15$ & $1.66 \% \pm 0.28$ \\
Transection, plus neuregulin & $0.72 \% \pm 0.24^{a}$ & $0.97 \% \pm 0.23^{b}$ \\
No transection, no neuregulin & $1.68 \% \pm 0.54$ & $2.40 \% \pm 0.41$ \\
No transection, plus neuregulin & $0.38 \% \pm 0.23^{c}$ & $1.68 \% \pm 0.39^{d}$
\end{tabular}

Newborn rats were divided into four treatment groups, three animals per group (see Materials and Methods). One day after transection, the distal stumps from transected nerves, the corresponding segment from unlesioned nerves, and the contralateral nerves were removed and processed for the TUNEL assay. TUNELpositive nuclei were counted, and their percentage of the total was calculated (see Materials and Methods). The \% TUNEL-positive nuclei in the left and right sciatic nerves from animals that received neuregulin were compared with those in animals that received vehicle alone by a paired, two-tailed $t$ test.

${ }^{a}$ The number of apoptotic cells in transected nerves from animals that received neuregulin was significantly less than that in transected nerves from animals that received vehicle alone $(p<0.0001)$.

${ }^{b, d}$ Although neuregulin reduced the percentage of TUNEL-positive cells in the contralateral leg in both the transected and the nontransected animals, this reduction did not achieve statistical significance in either group.

${ }^{c}$ The number of apoptotic cells in nontransected nerves from animals that received neuregulin was significantaly less than that in nontransected nerves from animals that received vehicle alone $(p<0.05)$.

weeks, and axotomy greatly augments the number of apoptotic Schwann cells during this developmental window but not in older animals. Schwann cells in these neonatal nerves express a neuregulin receptor composed of erbB2 (also known as c-neu) and erbB3, both of which are phosphorylated in vivo, presumably in response to endogenous neuregulins. Exogenous neuregulin completely abolishes the increase in apoptotic Schwann cells induced by axotomy. The apoptotic Schwann cells do not express myelinrelated proteins but do express the low-affinity nerve growth factor receptor (NGFR)/p75 and erbB2. These results demonstrate that one of the ways axon-Schwann cell interactions regulate Schwann cell number in developing nerves is through apoptosis, and they suggest that competition for a limited amount of axonally derived neuregulin may be the mechanism for pruning excessive Schwann cells generated during development.

\section{MATERIALS AND METHODS}

Surgery and injection of neuregulin. All animal protocols were approved by the Institutional Animal Care and Use Committee of The University of Pennsylvania. Newborn [the day of birth is considered to be postnatal day zero (P0)] and P5 rats were anesthetized in an ice-water bath. Using aseptic technique, the left sciatic nerve was exposed at the sciatic notch and transected with fine scissors. The right sciatic nerve was not lesioned and served as a control. The skin was closed with suture, and the pups were resuscitated by warming and then returned to their mothers. P20 and young adult (P90) Sprague-Dawley rats were anesthetized with pentobarbital $(50 \mathrm{mg} / \mathrm{kg}$, i.p.), and the sciatic nerve was exposed at the sciatic notch and transected with fine scissors. In adult rats that were allowed to survive for $>4 \mathrm{~d}$, permanent axotomy was accomplished by doubly ligating nerves, transecting between the ligatures with fine scissors, and suturing; the two nerve stumps were at least $1 \mathrm{~cm}$ apart. This technique prevents axonal regeneration to the distal nerve stump for at least 2 months. At various times after nerve injury, the animals were killed by $\mathrm{CO}_{2}$ inhalation, the distal nerve stumps were removed, and the most proximal $2-3 \mathrm{~mm}$ were trimmed off and processed as described below. Nerves from unlesioned animals were prepared similarly.

Two groups of experiments were carried out. (1) To establish the time course of apoptosis after axotomy at P0, P5, and P20, animals were killed $1,2,3$, or $4 \mathrm{~d}$ postlesion. P90 animals were killed after $1,4,8,12,24$, and 58 d. (2) To determine whether neuregulin could rescue axotomized Schwann cells, a recombinant human (rh) secreted $\beta$ isoform of neuregu- lin [rhGGF2 after the nomenclature in Marchionni et al. (1993)] dissolved in $200 \mathrm{~mm} \mathrm{NaCl}$ in $20 \mathrm{~mm}$ acetate buffer, $\mathrm{pH} 6.5$, was injected into the left thigh at a dose of $1.0 \mu \mathrm{g} / \mathrm{gm}$ body mass. The first injection was carried out $6 \mathrm{hr}$ before axotomy of the left sciatic nerve, the second at the time of axotomy, and the third and fourth, 8 and $16 \mathrm{hr}$ after axotomy. The animals were killed $24 \mathrm{hr}$ after axotomy. As controls, littermates were injected with an identical volume of the vehicle on the same schedule. Both the left (lesioned) and right (unlesioned) nerves were removed for analysis.

Terminal deoxynucleotidyl transferase (TdT)-mediated dUTP-biotin nickend labeling (TUNEL) assay and immunohistochemistry. Nerves were fixed overnight in $4 \%$ paraformaldehyde in $0.1 \mathrm{M}$ phosphate buffer, $\mathrm{pH} 7.4$, freshly prepared from paraformaldehyde, cryoprotected in $20 \%$ sucrose in $0.1 \mathrm{M}$ phosphate buffer, $\mathrm{pH} 7.4$, and embedded in OCT (Miles, Elkhart, IN). Longitudinal sections, $5 \mu \mathrm{m}$ thick, were mounted on Superfrost (Fisher Scientific, Orangeburg, NY) glass slides. For immunostaining, the sections were blocked for at least $1 \mathrm{hr}(20 \%$ fetal calf serum, $1 \% \mathrm{BSA}$, $0.1 \%$ Triton X-100, $0.05 \%$ sodium azide, in PBS) and incubated $24-48 \mathrm{hr}$ at $4^{\circ} \mathrm{C}$ with one of the following antibodies: mouse monoclonal antibodies against the low-affinity NGFR/p75 (Chandler et al., 1985), rat erbB2 (Oncogene Science \#4, Oncogene Science, Manhasset, NY) and rabbit polyclonal antibodies against rat S100 $\beta$ (EastAcres Biologicals, Southbridge, MA), periaxin (Gillespie et al., 1994), or erbB2 (Santa Cruz SC284, Santa Cruz Biotechnology, Tebu,France). We also stained sections of neonatal rat sciatic nerve with two additional monoclonal antibodies against erbB2 (Oncogene Science \#2, Oncogene Science, and Cambridge Research Biochemicals, Cheshire, UK), as well as two polyclonal rabbit antisera against erbB2 (E19420, Transduction Labs, Lexington, KY, and SC284, Santa Cruz Biotechnology). All of these erbB2 antibodies gave the same pattern of staining in sections of rat sciatic nerve by immunofluorescence. Three different rabbit polyclonal antisera against erbB3 [SC285, Santa Cruz Biotechnology; E38530, Transduction Laboratories; and gift of Dr. Kermit Carraway (Soltoff et al., 1994)], and a rabbit polyclonal antisera against erbB4 antisera (Santa Cruz SC283) did not label sections of neonatal rat sciatic nerve. After they were incubated with the primary antibodies, the sections were washed and then incubated with the appropriate fluorescein-conjugated goat anti-rabbit or anti-mouse secondary antibody (Cappel Division of Organon-Teknica, Malvern, PA).

After the immunohistochemistry, we used a modification of the TUNEL assay (Gavrieli et al., 1992). Sections were incubated in $0.5 \%$ Triton X-100 for $15 \mathrm{~min}$ at room temperature and preequilibrated in TdT buffer (30 mM Trizma base, $\mathrm{pH}$ 7.2, $140 \mathrm{~mm}$ sodium cacodylate, $1 \mathrm{~mm}$ cobalt chloride) before the addition of TdT (18 U/coverslip) and biotinylated dUTP. The sections were incubated at $37^{\circ} \mathrm{C}$ for $60 \mathrm{~min}$, and then the reaction was terminated by incubating in buffer $(300 \mathrm{~mm}$ sodium chloride, $30 \mathrm{~mm}$ sodium citrate) for $15 \mathrm{~min}$ at room temperature. The sections were rinsed in PBS containing 2\% BSA for 10 min, incubated in strepavidin rhodamine diluted 1:50 in PBS for $30 \mathrm{~min}$ at room temperature followed by rinsing in PBS. 4,6-Diamidino-2-phenylidole (DAPI) was applied to the sections for $5 \mathrm{~min}$ at room temperature to counterstain the nuclei. The sections were washed in PBS, mounted in Vectashield (Vector Labs, Burlingame, CA), coverslipped, and examined with a Leica TCS confocal microscopy system.

To quantify Schwann cell apoptosis, two or more longitudinal sections of sciatic nerve were mounted on a slide. The slide was oriented so that the top of each section was at the top of the microscope field. Using the $100 \times$ lens, we counted all of the nuclei (using DAPI fluorescence) in that field, as well as all of the TUNEL-positive cells (using rhodamine fluorescence). Each field was counted at least twice and a third or even a fourth time if the numbers did not agree sufficiently, and an average was determined. Then the stage was moved so that the very bottom of the first field was now at the very top of the second, and the counting process was repeated. In this way, three to five fields were counted from the "top" to the "bottom" of each section. Every section was counted. Because each field in animals from P0 to P6 contained $\sim 100$ cells, at least 1000 cells were analyzed at these critical time points. Because there were progressively fewer cells per field in P21 and P90 animals (see Fig. 1), fewer cells were analyzed, but this did not invalidate our ability to determine that there were few apoptotic cells at these ages. When more than one animal received the same experimental treatment, nerve sections from each animal were mounted on separate slides, counted separately, and averaged.

Electron microscopy. The left sciatic nerve was transected at P1, and the rat was killed at P3. The distal nerve stump of the left nerve, and the 
corresponding portion of the right sciatic nerve were removed and fixed

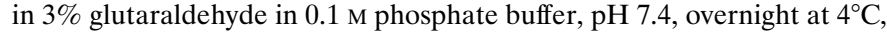
washed in $0.1 \mathrm{M}$ phosphate buffer, osmicated, dehydrated, and embedded in epoxy. Thin sections were stained with uranyl acetate and lead citrate and examined with a Zeiss electron microscope.

Western blotting and immunoprecipitation. Cultured rat Schwann cells (Brockes et al., 1979) were treated with $20 \mathrm{ng} / \mathrm{ml} \mathrm{rhGGF2} \mathrm{for} 2.5 \mathrm{~min}$ at $37^{\circ} \mathrm{C}$ to activate $\operatorname{erb} \mathrm{B}$ receptor tyrosine kinases. Cells were rinsed once with PBS and then incubated on ice for $10 \mathrm{~min}$ with chilled lysis buffer [buffer A: $50 \mathrm{~mm}$ Tris $\mathrm{HCl}, \mathrm{pH}$ 7.5, $150 \mathrm{~mm} \mathrm{NaCl}, 5 \mathrm{~mm}$ EGTA, 1\% NP40, $10 \%$ glycerol containing the protease and phosphatase inhibitors sodium orthovanadate $(1 \mathrm{~mm})$, sodium molybdate $(10 \mathrm{~mm}), \mathrm{NaF}(4 \mathrm{gm} / \mathrm{l})$, sodium pyrophosphate decahydrate $(8.8 \mathrm{gm} / \mathrm{l})$, phenylmethylsulfonyl fluoride (1 $\mathrm{mM})$, aprotonin $(10 \mu \mathrm{g} / \mathrm{ml})$, and leupeptin $(20 \mu \mathrm{M})$, all of which were added just before use]. Lysates were collected and then clarified by spinning in a microfuge for $10 \mathrm{~min}$ at $4^{\circ} \mathrm{C}$. The supernatants were aliquoted and stored at $-80^{\circ} \mathrm{C}$. $\mathrm{P} 1$ rat pups were decapitated, and their sciatic nerves, cerebella, and cerebra were removed and immediately frozen in liquid nitrogen. Frozen samples were diced with a razor blade on dry ice and then homogenized with eight strokes in a Dounce homogenizer in chilled buffer A as above. Samples were clarified by centrifugation in a microfuge for $10 \mathrm{~min}$ at $4^{\circ} \mathrm{C}$ and stored at $-80^{\circ} \mathrm{C}$.

For direct Western blot analysis, samples were mixed with gel-loading buffer containing $1 \mathrm{~mm}$ sodium orthovanadate, denatured (10 min, $100^{\circ} \mathrm{C}$ ), separated on $8 \mathrm{~cm} 8 \%$ polyacrylamide Tris-glycine gels (Novex, San Diego, CA), and blotted onto nitrocellulose. The filters were labeled with rabbit antisera against erbB2 (Santa Cruz SC284), erbB3 (Santa Cruz SC285), and erbB4 (one from Santa Cruz SC283), and four different antisera from Dr. Cary Lai), and phosphotyrosine (Transduction Laboratories). The antibodies were detected using horseradish peroxidasecoupled antisera against rabbit immunoglobulin and ECL reagents from Amersham (Arlington Heights, IL), according to the their instructions, and exposed to XAR-5 film (Kodak). Each of these antibodies gave a signal band in the size range that was appropriate for erbB2, erbB3, and erbB4 ( p185), as well as other bands. To determine directly the specificity of the Santa Cruz antisera against erbB2 and erbB3, peptide neutralization experiments were performed on Schwann cell protein extracts following the protocol recommended by the manufacturer. Ten micrograms of peptide against which the antiserum was raised were incubated with $1 \mu \mathrm{g}$ of antiserum in a $60 \mu \mathrm{l}$ mixture for $2 \mathrm{hr}$ at room temperature. This mixture was then diluted 1:1000 in the blocking solution used in the hybridizations (Tris-buffered saline/1\% powdered milk) and was hybridized with a blot of Schwann cell protein extract. The band in the p185 region of the gel was blocked by preincubation with peptide for both $e r b \mathrm{~B} 2$ and $e r b \mathrm{~B} 3$, whereas the nonspecific bands were not consistently affected (data not shown).

For immunoprecipitation, samples were first mixed with the phosphotyrosine antisera (Transduction Labs) and then with strepavidin-agarose beads (Pierce, Rockford, IL) at $4^{\circ} \mathrm{C}$. The beads were collected and washed three times in buffer $\mathrm{A}$, and the immunoprecipitates were eluted by boiling for $10 \mathrm{~min}$ in $2 \times$ gel-loading buffer. The eluted samples were transferred to fresh tubes, and equal portions were analyzed separately by Western blotting for erbB2 or erbB3, as described above. Immunoprecipitated Western blots had only a single band, located in the p185 region of the gel, further documenting the specificity of the antisera for $e r b \mathrm{~B} 2$ or erbB3.

\section{RESULTS}

\section{Apoptotic Schwann cells are present in sciatic nerve during early development but not at later stages}

To determine whether Schwann cells undergo apoptosis during normal development, we examined sections of rat sciatic nerve beginning at $\mathrm{P} 0$ through adulthood (P90) using the TUNEL assay (Gavrieli et al., 1992). As shown in Figure 1, there were occasional TUNEL-positive nuclei in nerves at $\mathrm{P} 0$ and $\mathrm{P} 6$; these were rarely seen by P21, and none were seen at P90. When viewed with DAPI nuclear counterstain, these TUNEL-positive nuclei were smaller than normal Schwann cell nuclei and had clumped chromatin, both of which are features of apoptotic nuclei (Kerr, 1971). There were also clusters of round TUNEL-positive structures, probably apoptotic bodies containing fragmented nuclei (Kerr et al., 1972).
Thus, apoptosis is a prominent, developmentally regulated feature of peripheral nerve.

\section{Axotomy greatly increases Schwann cell apoptosis but only during early development}

To determine whether axon-Schwann cell interactions regulate apoptosis, we transected the sciatic nerve to cause axonal degeneration. This was carried out both during (P0 and P5) and after (P20 and P90) the normal period of apoptosis. In the P0, P5, and P20 animals, the distal nerve stump was analyzed at 1, 2, 3, or $4 \mathrm{~d}$ after axotomy; in the P90 animals, this analysis was extended to include $8,12,24$, and $58 \mathrm{~d}$ postlesion. Unlesioned nerves from age-matched animals were used as controls. The sections were labeled for TUNEL and counterstained with DAPI so that the proportion of apoptotic nuclei could be determined.

The results of this experiment are summarized in Figure 2. Our counts demonstrated that between 1 and $1.2 \%$ of the Schwann cells died by apoptosis during the first $3 \mathrm{~d}$ of development. For axotomy at $\mathrm{P} 0$, the number of apoptotic nuclei increased 10 -fold $1 \mathrm{~d}$ postaxotomy, and then fell to within range of the controls by 3 d postaxotomy. To corroborate these observations, we compared the total number of intact nuclei in the distal nerve stump of axotomized and aged-matched, unaxotomized controls. There were $24 \%$ and $35 \%$ fewer nuclei in lesioned nerves at 2 and $3 \mathrm{~d}$ postaxotomy, respectively; this may be an underestimate of the loss of Schwann cells, because macrophages are known to infiltrate degenerating nerves (Griffin and Hoffman, 1993). Axotomy at $\mathrm{P5}$ resulted in a smaller (threefold) increase in the number of apoptotic nuclei at $1 \mathrm{~d}$ postaxotomy, followed by a decline to control levels (Fig. 2). Unlike axotomy at P0, however, there was no significant decline in the total number of nuclei at any of the time points after axotomy (data not shown). Axotomy at P20 (examined at 1 and 4 d postaxotomy) or P90 (examined at 1, 4, 8, 12,24 , and 60 d postaxotomy; data not shown) did not cause an increased number of apoptotic nuclei. These data indicate that there may be a window of susceptibility to axotomy-induced apoptosis in developing nerve, and the timing of this window corresponds to the normal period of Schwann cell apoptosis during development.

To evaluate further Schwann cell apoptosis after axotomy, we performed electron microscopy (Fig. 3) on the distal nerve stumps of P3 sciatic nerves that had been axotomized $2 \mathrm{~d}$ earlier (at P1), as well as on age-matched, unlesioned nerves. In lesioned nerves, most Schwann cells were not associated with any axons, indicating that most axons had already degenerated. Nearly all of the remaining axons had abnormal ultrastructural features, such as accumulations of dense bodies, neurofilaments, or smooth endoplasmic reticulum, indicating that they were degenerating (Griffin and Hoffman, 1993). There were several apoptotic nuclei per section in the lesioned nerves, and none in the unlesioned nerves. The apoptotic nuclei appeared to be within Schwann cells, because they were found within basal laminae; they were not surrounded by an extra cell membrane, which would be expected if they had been phagocytosed by other Schwann cells or macrophages. Unlike normal Schwann cell nuclei, apoptotic nuclei had large amounts of heterochromatin apposed to the inner aspect of the nuclear membrane, and at more advanced stages, the chromatin and Schwann cell cytoplasm became electron-lucent. This sequence of degenerative changes in the nucleus and cytoplasm is characteristic of apoptosis in other cell types (Kerr, 1971; Kerr et al., 1972; Arends et al., 1990), and hence confirms that denervation leads to apoptosis in neonatal sciatic nerve. 

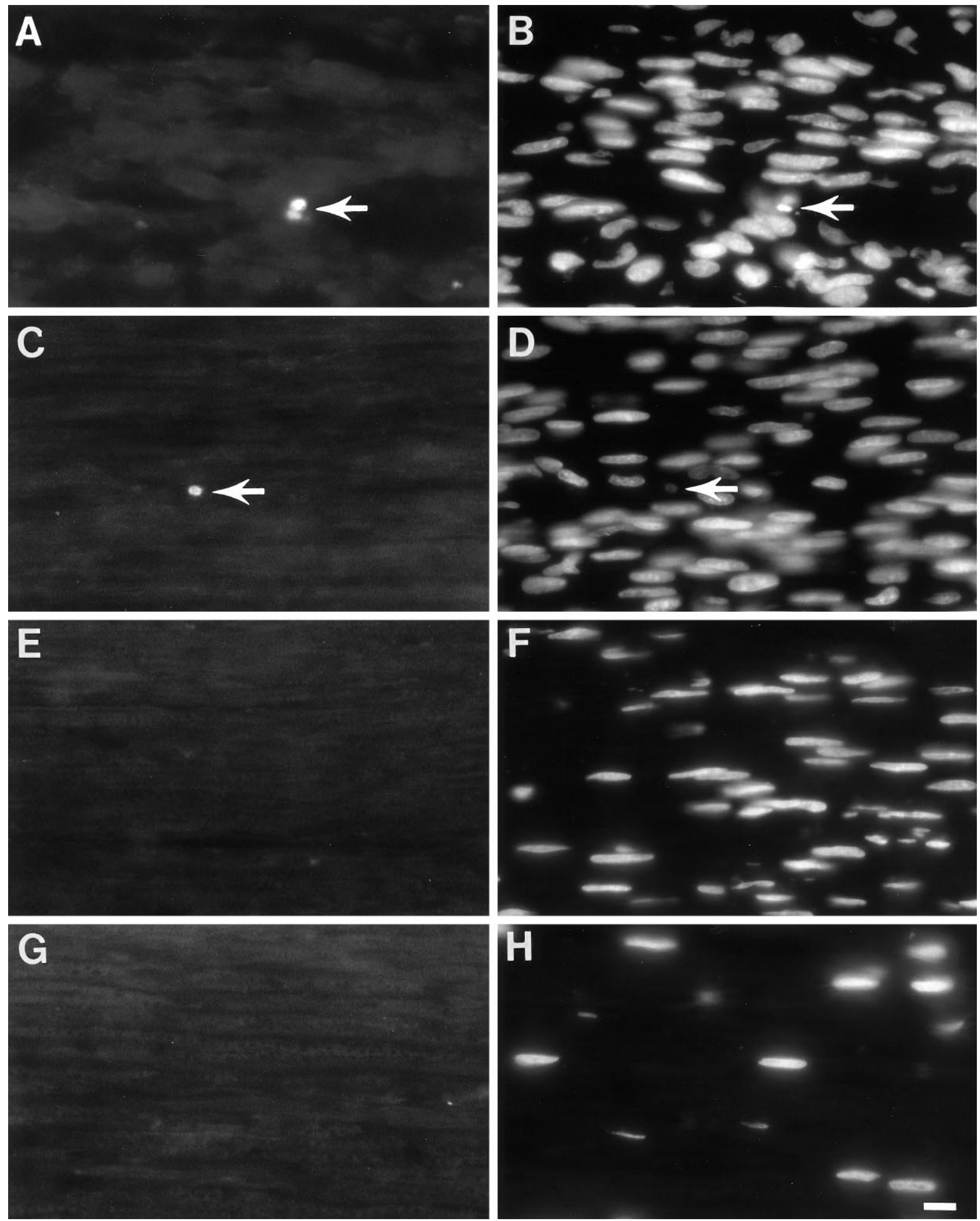

Figure 1. Apoptotic Schwann cells are found in neonatal but not adult rat sciatic nerve. These are photomicrographs of longitudinal sections of nerve, labeled by the TUNEL assay (left: $A, C, E, G)$ and DAPI, a nuclear counterstain (right: $B, D, F, H)$. There are a few apoptotic nuclei (arrows) at P0 ( $A$, $B)$ and P6 $(C, D)$, but none at P21 $(E, F)$ and P90 $(G, H)$. Scale bar, $10 \mu \mathrm{m}$.

\section{Apoptotic Schwann cells display a predominately premyelinating phenotype}

To determine the phenotype of apoptotic cells, we used immunofluorescence to double-label TUNEL-positive nuclei with a panel of Schwann cell markers. Neonatal nerves contain cells that are destined to become either myelinating or nonmyelinating
Schwann cells. We stained sections of P0 and P6 nerves for the pan-Schwann cell marker S100 $\beta$, the low-affinity NGFR/p75, which stains premyelinating and nonmyelinating Schwann cells, and periaxin, which is one of the earliest markers of myelinating Schwann cells (Stemple and Anderson, 1991; Gillespie et al., 1994; Scherer et al., 1995). We determined whether a TUNEL- 


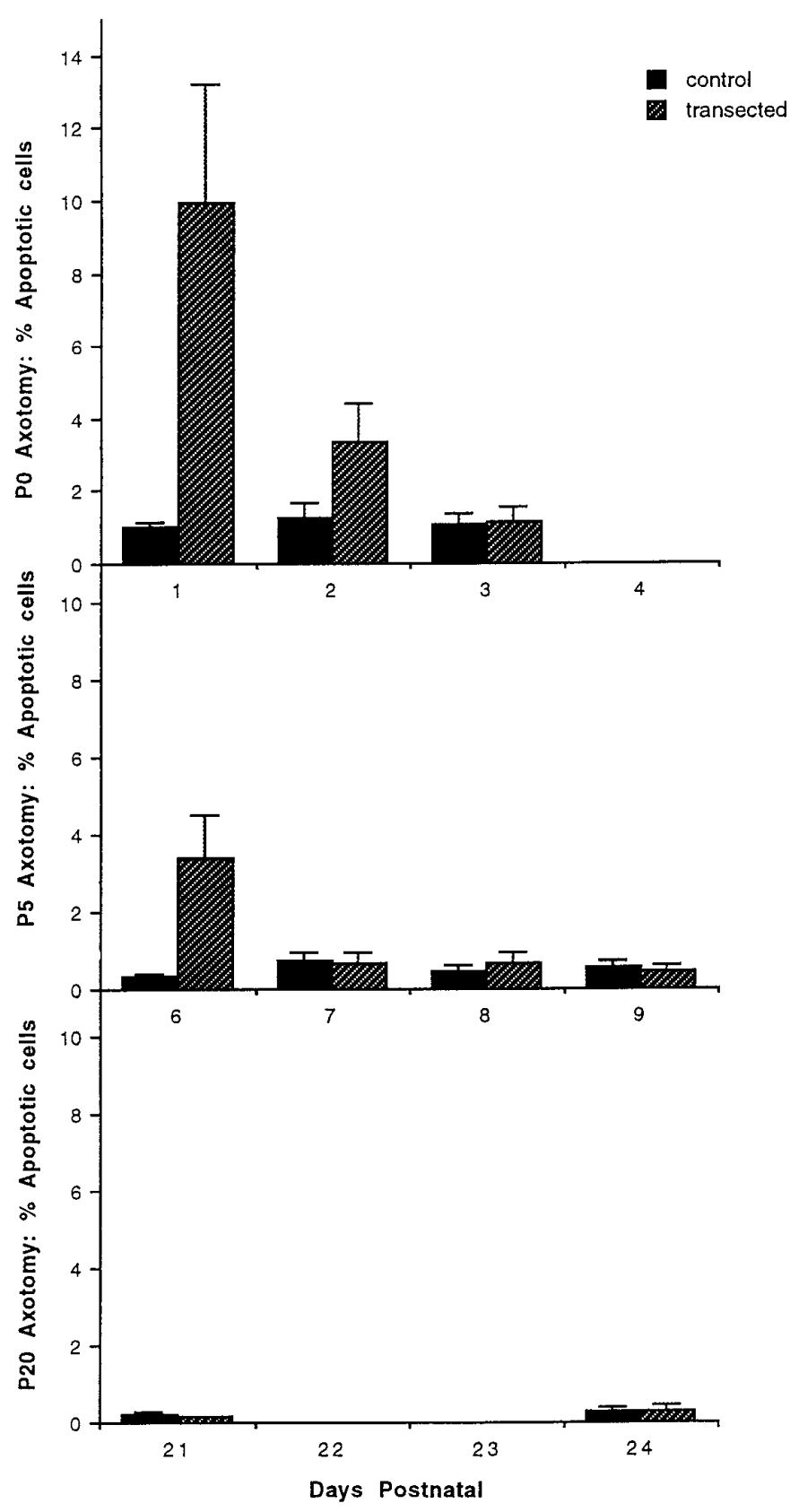

Figure 2. Axotomy increases Schwann cell apoptosis during early development. The distal nerve stumps of sciatic nerves that were transected at P0, P5, and P20 (cross-hatched bars), and age-matched unlesioned nerves (solid bars) were removed and processed for detection of apoptosis by the TUNEL assay. The data represent the mean percentage of apoptotic cells in 10 representative fields from three to four sections of each nerve. Error bars represent SEM.

positive nucleus was within a S100 $\beta$-, NGFR/p75-, or periaxinpositive cell by focusing through each TUNEL-positive cell using conventional epifluorescence. In photographing these sections, however, both conventional epifluorescence and confocal microscopy with image stacking gave less than optimal results. Instead, as shown in Figure 4, we photographed single optical sections with a confocal microscope and enhanced the brightness of the rhodamine signal to make it clearly visible.

Nearly all of the apoptotic nuclei were found in $\mathrm{S} 100 \beta$-positive cells, demonstrating that they were Schwann cells. When viewed
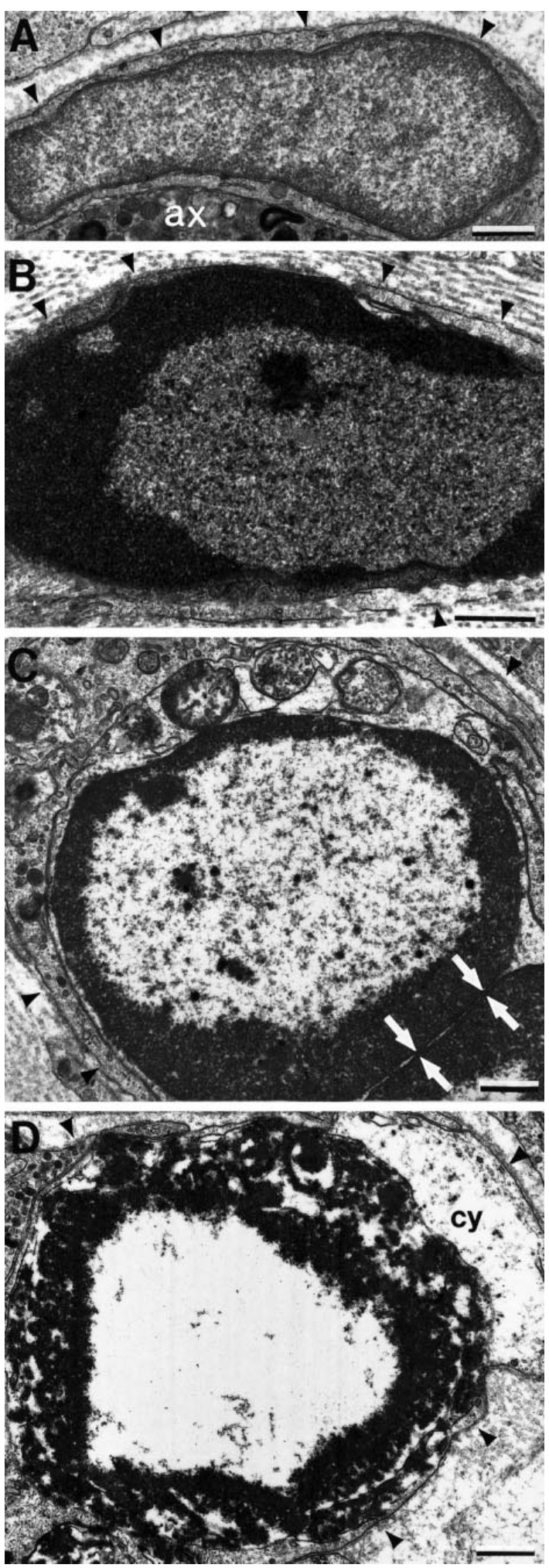

Figure 3. Electron microscopy of apoptotic Schwann cells. These are electron micrographs of Schwann cell nuclei in the distal nerve stump of a P3 rat sciatic nerve, $2 \mathrm{~d}$ after transection. $A$ shows a normal Schwann cell nucleus that is associated with a degenerating axon $(a x)$. $B-D$ show apoptotic nuclei in various stages of degeneration. All of the nuclei in $B-D$ have condensed chromatin on the inside of the nuclear membrane. In addition, the nucleoplasm is rarified in $C$ and $D$, and cytoplasm (cy) is rarified in $D$. The arrows in $C$ indicate an apparent separation of the nucleus into two fragments. In all panels, the arrowheads point to the basal lamina. Scale bars, $1 \mu \mathrm{m}$. 

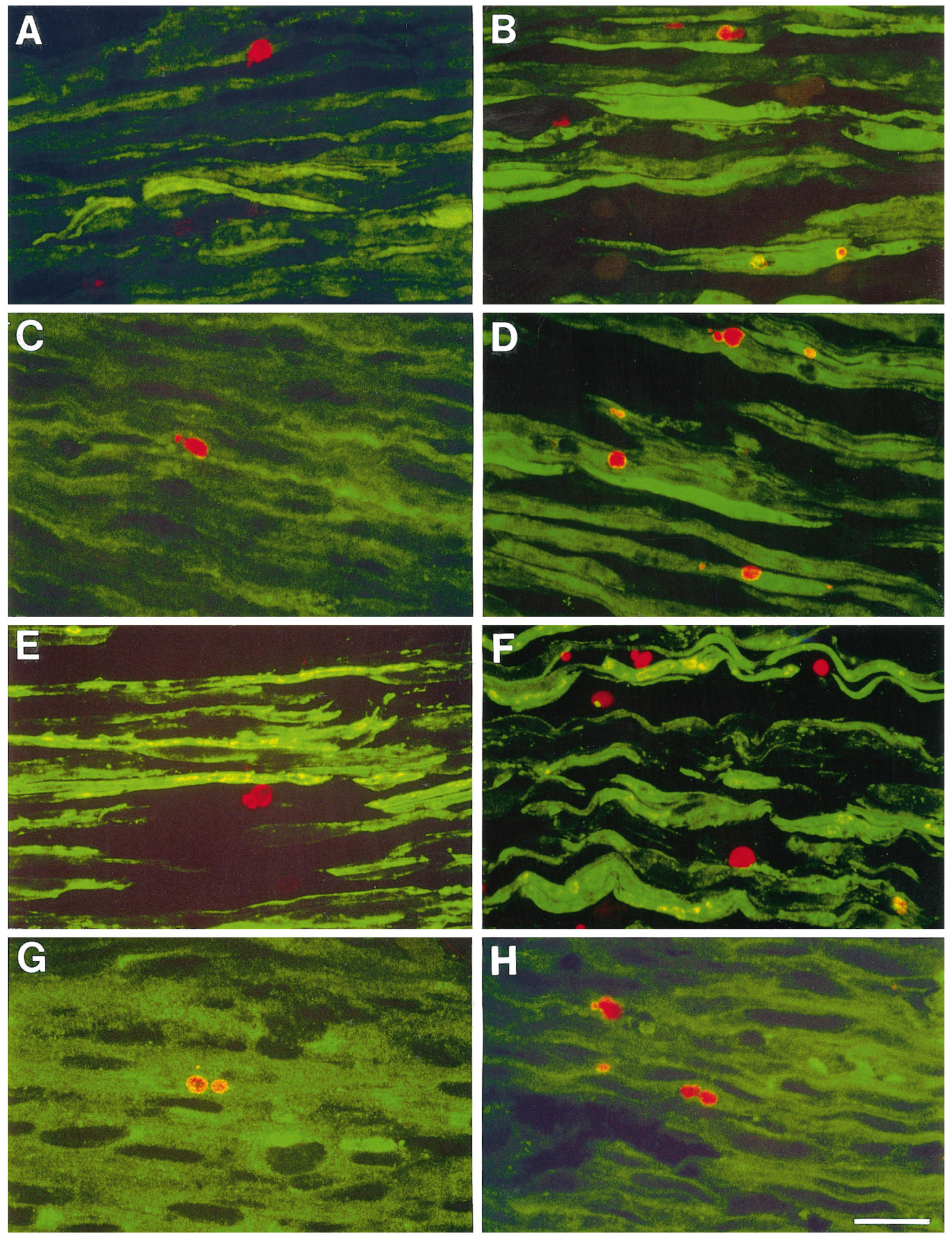

Figure 4. The immunophenotype of apoptotic Schwann cells in normal development and $1 \mathrm{~d}$ postaxotomy. These are confocal photomicrographs of sections taken from nerves transected at P0 (right), or their contralateral unlesioned counterparts (left). The sections were labeled for TUNEL (rhodamine) as well as $\mathrm{S} 100 \beta(A, B)$, NGFR $(C, D)$, periaxin $(E, F)$, or $\operatorname{erbB} 2(G, H)$, which were visualized with fluorescein optics. These confocal images were enhanced to make the TUNEL-positive cells more visible, with the untoward effect of making the nucleus appear to "pop out" of the fluorescein-positive cytoplasm. TUNEL-positive nuclei are seen within fluorescently labeled cells for the S100 $\beta$-, NGFR-, and $e r b$ B2-labeled sections. Fluorescently labeled cells with TUNEL-negative nuclei appear as dark spaces within the cells (arrows). In $E$ and $F$, the TUNEL-positive nuclei are not seen within the periaxin-labeled cells. Together, these photomicrographs demonstrate that the TUNEL-positive cells are Schwann cells (S100 $\beta$-positive), mostly premyelinating (erbB2-positive and NGFR-positive, but periaxin-negative). Scale bar, $10 \mu \mathrm{m}$. 
by conventional epifluorescence, one could clearly see TUNELpositive nuclei surrounded by $\mathrm{S} 100 \beta$-immunoreactivity (Fig. $4 A$ ), although in many cells the $\mathrm{S} 100 \beta$-immunoreactivity extended into the nucleus (Mata et al., 1990). Most TUNEL-positive nuclei were contained within the NGFR/p75-positive cells (Fig. 4C), indicating that they were in premyelinating Schwann cells. In the periaxin-labeled sections, positive nuclei appeared adjacent to but not within the fluorescently labeled cells, with few exceptions (Fig. $4 E$ ). These results demonstrate that during normal development, myelinating Schwann cells are relatively less likely to undergo apoptosis than premyelinating Schwann cells.

We also determined the phenotype of TUNEL-positive cells in lesioned neonatal nerves. For these experiments, we analyzed nerves from P1 animals 1 d postaxotomy, at the peak of Schwann cell apoptosis, because the large number of TUNEL-positive cells permitted a quantitative analysis. Although the dense packing of Schwann cells in neonatal nerves made it difficult to determine the immunophenotype of every TUNEL-positive cell, $>90 \%$ of the cells containing apoptotic nuclei were NGFR-positive $(n=132$; $\mathrm{SE}=4 \%$ ); one example is shown in Figure $4 D$. Less than $8 \%$ were periaxin-positive $(n=160 ; \mathrm{SE}=3 \%)$; one example is shown in Figure $4 F$. Thus, in both unlesioned and axotomized nerves, the overwhelming majority of apoptotic Schwann cells have a premyelinating phenotype characterized by S100 $\beta$ and NGFR/p75 expression (Jessen and Mirsky, 1992), but only a subset of Schwann cells with this phenotype seems to undergo apoptosis.

\section{Premyelinating Schwann cells express erbB2 and erbB3, which are phosphorylated}

To evaluate further our results regarding the effects of neuregulin on apoptosis (see below), we also wished to determine whether apoptotic Schwann cells in vivo expressed a neuregulin receptor. We have shown previously that premyelinating but not myelinating Schwann cells express erbB2 (Cohen et al., 1992), which needs either $e r b \mathrm{~B} 3$ or $e r b \mathrm{~B} 4$ to form a heterodimeric receptor for neuregulin (Carraway and Cantley, 1994; Carraway and Burden, 1995; Marchionni, 1995). To determine whether these receptor components were present in neonatal nerves, we performed Western blot analysis and immunohistochemistry of neonatal rat sciatic nerves. By Western blot (Fig. 5A), although erbB2 and erbB3 were readily detected, $e r b \mathrm{~B} 4$ was not detected. In adult sciatic nerves, the level of $e r b \mathrm{~B} 2$ was substantially lower than in neonatal nerves, whereas the level of erbB3 was relatively unchanged (Fig. 5A). These results were confirmed by the use of additional antisera against erbB2, erbB3, and erbB4, and by blocking experiments using the specific peptides against which the antisera were raised (data not shown).

To localize erbB2, erbB3, and erbB4 in neonatal nerves, we used a number of different antisera. None of the antisera against erbB3 or erbB4 labeled cells in sections of neonatal nerves, regardless of whether the nerve was unfixed or fixed in paraformaldehyde or Zamboni's solution, even though we had demonstrated that erbB3 was present by Western blot analysis. Several monoclonal and polyclonal antibodies against erbB2, however, labeled Schwann cells, which was documented further by the double-labeling with antisera against $\mathrm{S} 100 \beta$ (data not shown). Although perineurial cells were also erbB2-positive, they make only a small contribution to the total amount of $e r b \mathrm{~B} 2$-positivity in neonatal nerve, so that the Western blot analysis (see below) mostly reflects the contribution of Schwann cells. In double-labeling experiments for TUNEL and $e r b \mathrm{~B} 2$, most TUNEL-positive nuclei were found in erbB2-positive cells in both unlesioned and lesioned neonatal
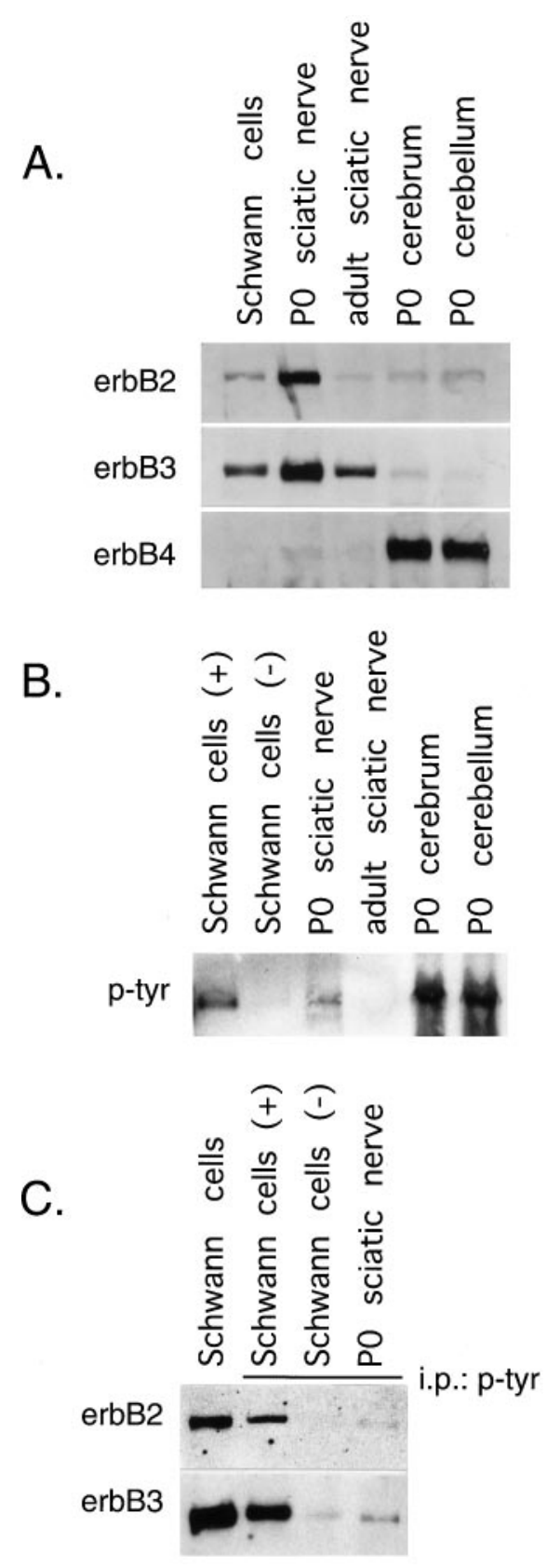

Figure 5. Expression and activation of neuregulin receptors in peripheral nerve glia. Lysates of cultured rat Schwann cells and homogenates of P0 and adult rat tissues were analyzed by Western blotting and immunoprecipitation as described in Materials and Methods. All panels display the p185 region of the gels. $A$ shows the expression of $e r b \mathrm{~B} 2$, erbB3, and $e r b \mathrm{~B} 4$. Both erbB2 and erbB3 are readily detected in cultured Schwann cells and in sciatic nerve. The level of erbB2 declines in adult sciatic nerve more so than that of erbB3. ErbB4 was not detected in Schwann cells or sciatic nerve, whereas it was detected readily in the cerebrum and cerebellum. $B$ shows the presence of phosphotyrosine in Schwann cells treated with rhGGF2, as well as P0 sciatic nerve, cerebrum, and cerebellum, but not in untreated Schwann cells or adult sciatic nerve. $C$ shows the result of the immunoprecipitation experiment. The left lane is a protein extract from Schwann cells; the three lanes that are underlined are phosphotyrosine immunoprecipitates from rhGGF2-treated $(+)$ or untreated $(-)$ Schwann cells and $\mathrm{P} 0$ rat sciatic nerve. Note that $\mathrm{P} 0$ sciatic nerve contains phosphorylated $e r b \mathrm{~B} 2$ and $e r b \mathrm{~B} 3$, and that treatment with rhGGF2 increased the amount of phosphorylated erbB2 and erbB3 in Schwann cells. 
nerves (Fig. 4G,H). These data, taken together, indicate that premyelinating Schwann cells express erbB2 and erbB3, and that some of these cells undergo apoptosis during normal development and after neonatal axotomy.

Because premyelinating Schwann cells seemed to have a functional neuregulin receptor, we examined the possibility that this receptor is phosphorylated in vivo by endogenous neuregulins, because binding of the erbB3 receptor in other cell types leads to phosphorylation of both erbB2 and erbB3 (Carraway and Cantley, 1994; Carraway and Burden, 1995). Western blots were prepared from the same material used to detect erbB2 and erbB3 and probed with a polyclonal antibody that recognizes phosphotyrosine residues. As shown in Figure $5 B$, neonatal but not adult sciatic nerve contained a phosphorylated protein of the appropriate size for either $e r b \mathrm{~B} 2$ or $e r b \mathrm{~B} 3(\sim 185 \mathrm{kDa})$, indicating that one or both of these proteins were phosphorylated in premyelinating Schwann cells. To demonstrate conclusively that this phosphorylated protein was $e r b \mathrm{~B} 2$ and/or erbB3, the same homogenate of neonatal nerves was immunoprecipitated with the antiphosphotyrosine polyclonal antibody, separated on a polyacrylamide gel, transferred to a nitrocellulose membrane, and probed for erbB2 and erbB3 (Fig. 5C). Protein extracts from cultured rat Schwann cells, which express both erbB2 and erbB3 (Levi et al., 1995), that had been grown in unsupplemented medium or medium supplemented with neuregulin, were used as negative and positive controls, respectively, for phosphorylated erbB2 and erbB3. Figure $5 C$ demonstrates that both erbB2 and erbB3 are phosphorylated in neonatal sciatic nerve, indicating that these receptors are activated in vivo by endogenous neuregulins. In control immunoprecipitations, we determined that the detection of phosphorylated receptors requires inclusion of the primary antiphosphotyrosine antibody.

\section{Apoptosis after axotomy and during normal development is prevented by addition of exogenous neuregulin}

The observations that Schwann cell precursors die in vitro after the withdrawal of growth factors, including neuregulins (Dong et al., 1995), and that neuregulins are made by PNS neurons and are axonally transported (Marchionni et al., 1993; Sandrock et al., 1995), raise the possibility that neuregulin regulates Schwann cell apoptosis in developing nerves. Axotomy could cause apoptosis by removing the axonal source of neuregulin, and exogenous neuregulin could rescue axotomized Schwann cells, as recently observed by Trachtenberg and Thompson (1996), at the neuromuscular junction. We tested this idea by injecting neuregulin into the axotomized (left) leg to maximize the availability of neuregulin to the axotomized Schwann cells in the distal nerve stump. Because the optimal amount of neuregulin, dosing frequency, and route of administration are not established, we arbitrarily chose to inject 1 $\mu \mathrm{g} / \mathrm{gm}$ body mass of neuregulin before, during, and after axotomy. We used a highly purified, recombinant secreted $\beta$ isoform of human neuregulin, termed rhGGF2 (Marchionni et al., 1993). Because the amount of axotomy-induced apoptosis is higher at birth, and the perineurial barrier is less developed in neonatal animals (Thomas and Olsson, 1984), we used pups at the youngest age possible, the day of birth. One litter of 12 newborn rats was used. Each experimental group consisted of three pups: one group was axotomized and treated with neuregulin; one group was axotomized and treated with vehicle alone; one group was not axotomized and treated with neu- regulin; and one group was not axotomized and was injected with vehicle. All of the animals were killed $24 \mathrm{hr}$ after axotomy, the time at which the number of TUNEL-positive nuclei was maximal (Fig. 2). Figure 6 shows a representative field from an axotomized animal that received vehicle alone and another field from an axotomized animal that was treated with neuregulin. Axotomized nerves that had received vehicle alone had many apoptotic Schwann cells, whereas axotomized nerves that received neuregulin had even fewer apoptotic cells than unlesioned nerves.

To evaluate these results quantitatively, we determined the percentage of apoptotic Schwann cells in each experimental group; these are tabulated in Table 1. The most striking result was that in neuregulin-treated animals, axotomy did not increase the number of TUNEL-positive nuclei. This effect cannot be attributed to the vehicle, because there was a 10 -fold increase in the number of apoptotic Schwann cells after axotomy in animals treated with vehicle alone, comparable to the increase described above (Fig. 2) after axotomy at P0. Neuregulin also seemed to lower the endogenous rate of apoptosis in developing Schwann cells. In unlesioned nerves, there were significantly fewer apoptotic Schwann cells after neuregulin administration than after treatment with vehicle alone $(p<0.05)$. In addition, the number of apoptotic Schwann cells found in the right sciatic nerve of the animal, which was never injected, tended to be lower in neuregulin-injected animals than in vehicle-injected animals, regardless of whether the left nerve was transected, but these differences did not achieve statistical significance. These results demonstrate that apoptotic Schwann cells can be rescued by neuregulin and are thus not destined to die. Rather, the number of Schwann cells in developing nerves seems to be molded by axon-Schwann cell interactions. Neuregulin thus may be one of the axonally derived factors that mediate Schwann cell survival.

\section{DISCUSSION}

Our results demonstrate that there is a transient period in developing nerves during which $1 \%$ of the Schwann cells undergo apoptosis. In this developmental window, Schwann cell apoptosis can be augmented 10 -fold by axotomy, demonstrating that survival is regulated by axon-Schwann cell interactions. During normal development and after axotomy, the cell death is limited to premyelinating Schwann cells. Administration of exogenous neuregulin prevents apoptosis after axotomy and also lowers the endogenous rate of apoptosis during development. Premyelinating Schwann cells probably express a neuregulin receptor composed of $e r b \mathrm{~B} 2$ and $e r b \mathrm{~B} 3$, and both of these receptor subunits are phosphorylated in vivo, presumably in response to endogenous neuregulin. These data suggest that axonally derived neuregulin regulates apoptosis in premyelinating Schwann cells during the development of peripheral nerve, via an $e r b \mathrm{~B} 2$ and $e r b \mathrm{~B} 3$ neuregulin receptor, and extend the known actions of neuregulins on the biology of Schwann cells.

\section{Premyelinating Schwann cells undergo apoptosis}

That Schwann cells undergo apoptosis has been recognized only recently. Jessen and colleagues found apoptosis in cultured Schwann cell precursors that are deprived of growth factors (Jessen et al., 1994; Dong et al., 1995; Gavrilovic et al., 1995). In these apoptotic precursors, the chromatin condenses in the characteristic way, and the DNA is nicked (Jessen et al., 1994). These precursors do not express $\mathrm{S} 100 \beta$, galactocerebroside, or sulfatide, and are earliest stages of developing Schwann cells (Jessen et al., 1994; Jessen and Mirsky, 1991, 1992; Stewart et al., 1995). Cul- 

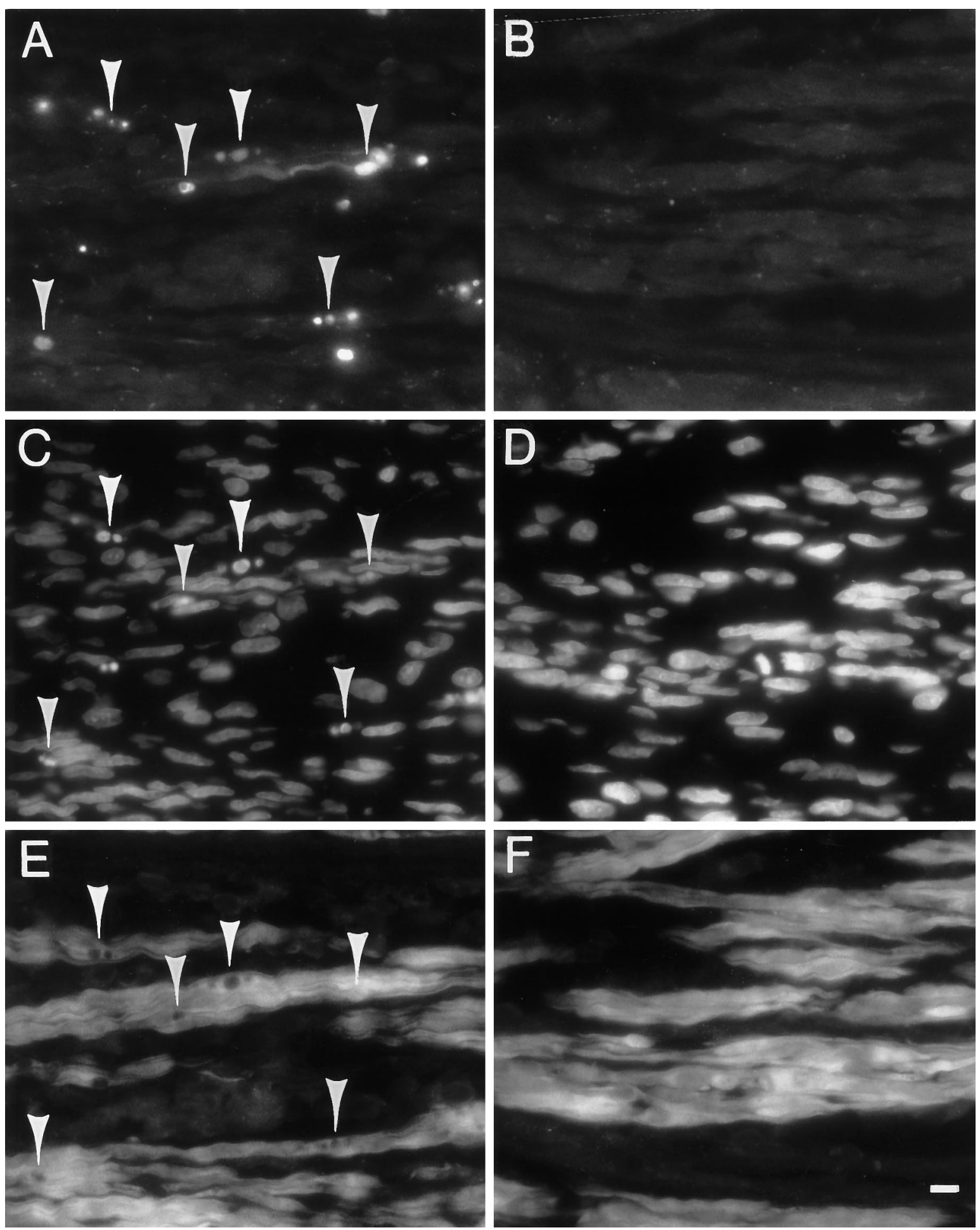

Figure 6. Neuregulin prevents Schwann cell apoptosis after axotomy. These are photomicrographs of longitudinal sections taken from sciatic nerve, $1 \mathrm{~d}$ after transection. $A, C$, and $E$ are from a vehicle-only treated animal, whereas $B, D$, and $F$ are from an animal treated with neuregulin. $A$ and $B$ show TUNEL staining; TUNEL-positive nuclei are indicated by arrowheads. Note that there are no apoptotic nuclei in the neuregulin-treated nerve. $C$ and $D$ show the DAPI counterstained nuclei; the arrows show that the TUNEL-positive nuclei (as in $A$ ) are fragmented. $E$ and $F$ show S100 $\beta$ staining; the arrowheads indicate the location of the apoptotic nuclei, which appear as a dark void within the Schwann cell cytoplasm. Scale bar, $10 \mu \mathrm{m}$.

tured precursors die unless FGF, IGF-1, or neuregulin is added to the medium; neuregulin is the most potent factor yet tested.

The apoptotic Schwann cells that we have found in neonatal nerves, however, are not Schwann cell precursors. Precursors are present transiently in embryonic nerves and do not express $\mathrm{S} 100 \beta$
(Jessen and Mirsky, 1992; Jessen et al., 1994; Stewart et al., 1995). In contrast, we and others (Trachtenberg and Thompson, 1996) have found apoptotic cells in neonatal nerves, in cells that expressed $\mathrm{S} 100 \beta$. We further characterized these apoptotic Schwann cells by showing that they were predominately premyelinating, 
because they expressed NGFR/p75 and not periaxin, one of the first myelin-related proteins expressed by myelinating Schwann cells (Gillespie et al., 1994; Scherer et al., 1995). These data indicate that there is a subpopulation of premyelinating Schwann cells in neonatal nerves that is susceptible to apoptosis, and that these cells disappear after the initial stages of development. Because Schwann cells are proliferating during the period of apoptosis (Brown and Asbury, 1981; Stewart et al., 1993), perhaps newly generated cells are the susceptible ones, as has been described in immature oligodendrocytes and stem cells in the subventricular zone (Barres et al., 1992; Morshead and van der Kooy, 1992). If newly generated Schwann cells require axonally derived neuregulins for their survival, then the occasional Schwann cells without axonal contact that we have observed in neonatal rodent nerves by electron microscopy (S.S. Scherer, personal observation) would be vulnerable. Whether these supernumerary Schwann cells are newly generated and the ones that are eliminated by apoptosis remains to be determined.

\section{Developing Schwann cells and oligodendroglia undergo axonally dependent apoptosis}

After axotomy, there was a rapid and striking increase in the number of apoptotic Schwann cells, but only in neonatal nerves. When transection was performed within the first week after birth, the number of apoptotic cells increased 10-fold within $1 \mathrm{~d}$ after transection. The number of apoptotic cells rapidly fell, so that $3 \mathrm{~d}$ after transection the number was back to baseline. As in unlesioned nerves, the apoptotic Schwann cells had a premyelinating phenotype. Our observations agree with those of Trachtenberg and Thompson (1996), who found that all terminal Schwann cells at developing neuromuscular junctions underwent apoptosis after axotomy, which was completely prevented by exogenous neuregulin. These workers did not evaluate the phenotype of the apoptotic Schwann cells and did not report apoptotic Schwann cells during normal development. In older animals, Schwann cell apoptosis was rarely detected in nontransected nerves and did not increase after axotomy. Our observations do not exclude the possibility that Schwann cells undergo apoptosis after transection of adult nerves, because Schwann cells seem to disappear slowly from the distal nerve stumps of chronically denervated nerves (Weinberg and Spencer, 1978). Our method of detecting apoptotic cells provides a snapshot of apoptosis and could easily miss a more protracted loss of cells.

Cell death during development and after axotomy has been reported in developing oligodendrocytes, although the methods used to identify the dead cells did not detect apoptosis per se (Barres et al., 1992, 1993a,b). As in Schwann cells, the proportion of dead oligodendrocytes in the optic nerve is higher during early development, both during normal development and after axotomy, although the time frame of accumulation and clearing of dead cells continues for several weeks. As in apoptotic Schwann cells, the oligodendrocytes that died after axotomy were unlikely to have made myelin sheaths. Finally, both developing oligodendrocytes and Schwann cells can be rescued by axonally derived trophic factors, which have been shown previously to modulate their particular maturation in vitro. Normal cell death of oligodendrocytes in vivo can be suppressed by the delivery of exogenous platelet-derived growth factor (PDGF) and ciliary neurotrophic factor (CNTF) (Barres et al., 1993b). CNTF or IGF-1 will also rescue axon-deprived oligodendroglia (Barres et al., 1993a).

\section{Neuregulin regulates axon-Schwann cell interactions}

Many aspects of Schwann cell development may be regulated by axon-Schwann cell interactions (Stewart et al., 1995; Scherer and Salzer, 1996). It is becoming increasingly clear that neuregulin may be one of the main mediators of these interactions, especially of the early events of Schwann cell development. It promotes the differentiation of Schwann cells from the neural crest (Shah et al., 1994), induces proliferation in precursors and neonatal and adult Schwann cells (Lemke, 1990; Eccleston, 1992; Levi et al., 1995; Rutkowski et al., 1995), and prevents apoptosis of precursors and neonatal Schwann cells (Dong et al., 1995; Trachtenberg and Thompson, 1996). The recent observation that Schwann cell precursors are deficient in mice lacking neuregulin attributable to disruption of the neuregulin gene (Meyer and Birchmeier, 1995) confirms that neuregulin plays an essential role in the early biology of Schwann cells.

There is accumulating evidence demonstrating that the effects of neuregulins on Schwann cells are mediated by the neuregulin receptor composed of erbB2 and erbB3. Previous workers have shown that neural crest cells, Schwann cell precursors, and premyelinating Schwann cells, but not myelinating Schwann cells, express erbB2 (Cohen et al., 1992; Shah et al., 1994; Dong et al., 1995). We found $e r b \mathrm{~B} 2$ and $e r b \mathrm{~B} 3$, but not erbB4, in neonatal nerves, suggesting that $e r b \mathrm{~B} 2$ and $e r b \mathrm{~B} 3$ form the neuregulin receptor in neonatal Schwann cells. These results are consistent with those of Levi et al. (1995), who detected erbB2 and erbB3 but not erbB4 in cultured human Schwann cells by Western blot analysis, and $e r b \mathrm{~B} 2$ and $e r b \mathrm{~B} 3 \mathrm{mRNA}$, as well as a lower level of erbB4 mRNA, by reverse transcription-PCR. It is likely that both $e r b \mathrm{~B} 2$ and $e r b \mathrm{~B} 3$ are needed to form a functional neuregulin receptor, because erbB2 does not directly bind neuregulins but is activated by interacting with $\operatorname{erb} \mathrm{B} 3$, which can bind neuregulins, but by itself seems to be incapable of transducing a signal (Carraway and Cantley, 1994; Carraway and Burden, 1995; Marchionni, 1995). If this is the case, then the fall in erbB2 expression during development may account for the lack of effect of neuregulin on maturing Schwann cells.

Like other receptor protein-tyrosine kinases (van der Geer et al., 1994), erbB2 and erbB3 are activated by phosphorylation (Carraway and Burden, 1995). Neuregulin leads to phosphorylation of erbB2 in cultured Schwann cells (Levi et al., 1995), and antibodies against erbB2 inhibit its phosphorylation and the effects of neuregulins on proliferation in vitro (Levi et al., 1995; Morrissey et al., 1995). Our demonstration that both erbB 2 and erbB 3 are phosphorylated in vivo in neonatal but not adult sciatic nerves is strong evidence that neuregulins are present in neonatal nerves and available to Schwann cells. Axons are the most abundant source of neuregulins in nerve (Sandrock et al., 1995), but exactly which isoforms are expressed by axons remains to be determined. Although there are other potential neuronal trophic factors for Schwann cells, including acidic FGF (Eckenstein et al., 1990), PDGF (Yeh et al., 1991), and gas6 (Li et al., 1996), neuregulin is the best example to date of a neuronal trophic factor that affects the development of Schwann cells.

The discovery of trophic factors for Schwann cells that are derived from PNS neurons reinforces the possibility that there are reciprocal trophic interactions between these cells (Reynolds and Woolf, 1993). If Schwann cells make survival factors for neurons during development, and neuronal trophic factors, in turn, support the survival of Schwann cells, then there would be a system for matching the numbers of neurons and Schwann cells during 
development (Cowan et al., 1984). In keeping with this proposal, Verdi et al. (1996) recently reported that cultured sympathetic neuroblasts provide neuregulins for non-neuronal cells, which in turn provide NT-3 for the neuroblasts. Reciprocal axon-Schwann cell interactions could also be involved in axonal regeneration in the PNS. It has long been appreciated that Schwann cells make trophic factors that seem to support the survival and alter the phenotype of PNS neurons during the process of axonal regeneration (Scherer and Salzer, 1996). The expression of neuregulins by regenerating axons, in turn, could regulate the proliferation and survival of Schwann cells in the distal nerve stump, because axotomy causes Schwann cells to reexpress erbB2 (Cohen et al., 1992).

\section{REFERENCES}

Arends MJ, Morris RG, Wyllie AH (1990) Apoptosis: the role of the endonuclease. Am J Pathol 136:593-608.

Barres BA, Hart IK, Coles HSR, Burne JF, Voyyodic JT, Richardson WD, Raff MC (1992) Cell death and control of cell survival in the oligodendrocyte lineage. Cell 70:31-46.

Barres BA, Jacobson MD, Schmid R, Sendtner M, Raff MC (1993a) Does oligodendrocyte survival depend on axons? Curr Biol 3:489-497.

Barres BA, Schmid R, Sendnter M, Raff MC (1993b) Multiple extracellular signals are required for long-term oligodendrocyte survival. Development 118:283-295.

Brockes JP, Fields P, Raff MC (1979) Studies on cultured rat Schwann cells. I. Establishment of purified populations from cultures of peripheral nerve. Brain Res 165:105-118.

Brockes JP, Lemke GE, Balzer Jr DR (1980) Purification and preliminary characterization of a glial growth factor from the bovine pituitary. J Biol Chem 255:8374-8377.

Brown MJ, Asbury AK (1981) Schwann cell proliferation in the postnatal mouse: timing and topography. Exp Neurol 74:170-186.

Carraway III KL, Cantley LC (1994) A neu acquaintance for erbB3 and erbB4: a role for receptor heterodimerization in growth signaling. Cell 78:5-8.

Carraway KLI, Burden SJ (1995) Neuregulins and their receptors. Curr Opin Neurobiol 5:606-612.

Chandler CE, Parsons LM, Hosang M, Shooter EM (1985) A monoclonal antibody modulates the interaction of nerve growth factor with PC12 cells. J Biol Chem 259:6882-6889.

Chen MS, Bermingham-McDonogh O, FT Danehy Jr J, Nolan C, Scherer SS, Lucas J, Gwynne D, Marchionni MA (1994) The expression of multiple neuregulin isoforms in postnatal rat brains. J Comp Neurol 349:389-400.

Cohen JA, Yachnis AT, Arai M, Davis JG, Scherer SS (1992) Expression of the neu proto-oncogene by Schwann cells during peripheral nerve development and Wallerian degeneration. J Neurosci Res 31:622-634.

Corfas G, Rosen KM, Aratake H, Krauss R, Fischbach GD (1995) Differential expression of ARIA isoforms in the rat brain. Neuron 14:103-115.

Cowan WM, Fawcett JW, O’Leary DDM, Stanfield BB (1984) Regressive events in neurogenesis. Science 225:1258-1265.

Dong Z, Brennan A, Liu N, Yarden Y, Lefkowitz G, Mirsky R, Jessen KR (1995) Neu differentiation factor acts as a neuron-glia signal and regulates the survival, proliferation and maturation of the rat Schwann cell precursor. Neuron 585-596.

Eccleston PA (1992) Regulation of Schwann cell proliferation: mechanisms involved in peripheral nerve development. Exp Cell Res 199:1-9.

Eckenstein FP, Esch F, Holbert T, Blacher RW, Nishi R (1990) Purification and characterization of a trophic factor for embryonic peripheral neurons: comparison with fibroblast growth factors. Neuron 4:623-631.

Gavrieli Y, Sherman Y, Ben-Sasson SA (1992) Identification of programmed cell death in situ via specific labeling of nuclear DNA fragmentation. J Cell Biol 119:493-501.

Gavrilovic J, Brennan A, Mirsky R, Jessen KR (1995) Fibroblast growth factors and insulin growth factors combine to promote survival of rat Schwann cell precursors without induction of DNA synthesis. Eur J Neurosci 7:77-85.

Gillespie CS, Sherman DL, Blair GE, Brophy PJ (1994) Periaxin, a novel protein of myelinating Schwann cells with a possible role in axonal ensheathment. Neuron 12:497-508.

Griffin JW, Hoffman PN (1993) Degeneration and regeneration in the peripheral nervous system. In: Peripheral neuropathy (Dyck PJ,
Thomas PK, Low PA, Poduslo JF, eds), pp 361-376. Philadelphia: W. B. Saunders.

Ho W-H, Armanini MP, Nuijens A, Phillips HS, Osheroff PL (1995) Sensory and motor neuron-derived factor: a novel heregulin variant highly expressed in sensory and motor neurons. J Biol Chem 270:14523-14532.

Jessen KR, Mirsky R (1991) Schwann cell precursors and their development. Glia 4:185-194.

Jessen KR, Mirsky R (1992) Schwann cells: early lineage, regulation of proliferation and control of myelin formation. Curr Opin Neurobiol 2:575-581.

Jessen KR, Brennan A, Morgan L, Mirsky R, Kent A, Hashimoto Y, Gavrilovic J (1994) The Schwann cell precursor and its fate: a study of cell death and differentiation during gliogenesis in rat embryonic nerves. Neuron 12:509-527.

Kerr JFR (1971) Shrinkage necrosis: a distinct mode of cellular death. J Pathol 105:13-20.

Kerr JFR, Wyllie AH, Currie AR (1972) Apoptosis: a basic phenomenon with wide ranging implications in tissue kinetics. $\mathrm{Br} \mathrm{J}$ Cancer 26:239-257.

Korsching S (1993) The neurotrophic factor concept: a reexamination. J Neurosci 13:2739-2748.

Lemke G (1990) Glial growth factors. Semin Neurosci 2:437-443.

Lemke G, Brockes JP (1984) Identification and purification of glial growth factor. J Neurosci 4:75-83.

Levi ADO, Bunge RP, Lofgren JA, Meima L, Hefti F, Nikolics K, Sliwkowski MX (1995a) The influence of heregulins on human Schwann cell proliferation. J Neurosci 15:1329-1340.

Li RH, Chen J, Hammonds G, Phillips H, Armanini M, Bunge R, Godowski PJ, Sliwkowski MX, Mather JP (1996) Identification of gas6 as a growth factor for human Schwann cells. J Neurosci 16:2012-2019.

Marchionni M (1995) Neu tack on neuregulin. Nature 378:334-335.

Marchionni MA, Goodearl ADJ, Chen MS, Bermingham-McDonogh O, Kirk C, Hendricks M, Danehy F, Misumi D, Sudhalter J, Kobayashi K, Wroblewski D, Lynch C, Baldassare M, Hiles I, Davis JB, Hsuan JJ, Totty NF, Otsu M, McBurney RN, Waterfield MD, Stroobant P, Gwynne D (1993) Glial growth factors are alternatively spliced erbB2 ligands expressed in the nervous system. Nature 362:312-318.

Mata M, Alessi D, Fink DJ (1990) S100 is preferentially distributed in myelin-forming Schwann cells. J Neurocytol 19:432-442.

Meyer D, Birchmeier C (1994) Distinct isoforms of neuregulin are expressed in mesenchymal and neuronal cells during mouse development. Proc Natl Acad Sci USA 91:1064-1068.

Meyer D, Birchmeier C (1995) Multiple essential functions of neurogulin in development. Nature 378:386-390.

Morrissey TK, Levi ADO, Nuijens A, Sliwkowski MX, Bunge RP (1995) Axon-induced mitogenesis of human Schwann cells involves heregulin and p185 ${ }^{\text {erbB2 }}$. Proc Natl Acad Sci USA 92:1431-1435.

Morshead CM, van der Kooy D (1992) Postmitotic death is the fate of constitutively proliferating cells in the subependymal layer of the adult mouse brain. J Neurosci 12:249-256.

Purves D, Lichtman JW (1985) Principles of neural development. Sunderland, MA: Sinauer.

Reynolds ML, Woolf CJ (1993) Reciprocal Schwann cell-axon interactions. Curr Opin Neurobiol 3:683-693.

Rutkowski JL, Kirk CJ, Lerner MA, Tennekoon GI (1995) Purification and expansion of human Schwann cells in vitro. Nat Med 1:80-83.

Sandrock Jr AW, Goodearl ADJ, Yin Q-W, Chang D, Fischbach GD (1995) ARIA is concentrated in nerve terminals at neuromuscular junctions and at other synapses. J Neurosci 15:6124-6136.

Scherer SS, Salzer JL (1996) Axon-Schwann cell interactions in peripheral nerve regeneration. In: Glial cell development (Jessen KR, Richardson WD, eds), pp 165-196. Oxford: Bios Scientific Publishers.

Scherer SS, Xu Y-t, Bannerman P, Sherman DL, Brophy PJ (1995) Periaxin expression in myelinating Schwann cells: modulation by axonglial interactions and polarized localization during development. Development 121:4265-4273.

Sen S (1992) Programmed cells death: concept, mechanism and controls. Biol Rev 67:287-319.

Shah NM, Marchionni MA, Issacs I, Stroobant P, Anderson DJ (1994) Glial growth factor restricts mammalian neural crest stem cells to a glial fate. Cell 77:349-360.

Snider WD (1994) Functions of the neurotrophins during nervous system development: what the knockouts are teaching us. Cell 77:627-638. 
Soltoff SP, Carraway KL, Prigent SA, Gullick WG, Cantley LC (1994) ErbB3 is involved in activation of phosphatidylinositol 3-kinase by epidermal growth factor. Mol Cell Biol 14:3550-3558.

Stemple DL, Anderson DJ (1991) A Schwann cell antigen recognized by monoclonal antibody $217 \mathrm{c}$ is the rat low-affinity nerve growth factor receptor. Neurosci Lett 124:57-60.

Stewart HJS, Morgan L, Jessen KR, Mirsky R (1993) Changes in DNA synthesis rate in the Schwann cell lineage in vivo are correlated with the precursor: Schwann cell transition and myelination. Eur $\mathbf{J}$ Neurosci 5:1136-1144.

Stewart HJS, Mirsky R, Jessen KR (1995) The Schwann cell lineage: embryonic and early postnatal development. In: Glial cell development (Jessen KR, Richardson WD, eds), pp 1-23. Oxford: Bios Scientific Publishers.

Thomas PK, Olsson Y (1984) Microscopic anatomy and function of the connective tissue components of peripheral nerve. In: Peripheral neuropathy (Dyck PJ, Thomas PK, Lambert EH, Bunge R, eds), pp 97-120. Philadelphia: W. B. Saunders.

Trachtenberg JT, Thompson WJ (1996) Schwann cell apoptosis and its regulation at the developing neuromuscular junction. Nature 379:174-177. van der Geer P, Hunter T, Lindberg RA (1994) Receptor proteintyrosine kinases and their signal transduction pathways. Annu Rev Cell Biol 10:251-337.

Verdi JM, Groves AK, Farinas I, Jones K, Marchionni MA, Reichardt LF, Anderson DJ (1996) A reciprocal cell-cell interaction mediated by NT-3 and neuregulins controls the early survival and development of sympathetic neuroblasts. Neuron 16:515-527.

Weinberg HJ, Spencer PS (1978) The fate of Schwann cells isolated from axonal contact. J Neurocytol 7:555-569.

Wen D, Suggs SV, Karunagaran D, Liu N, Cupples RL, Luo Y, Janssen AM, Ben-Baruch N, Trollinger DB, Jacobsen VL, Meng S-Y, Lu SH, Hu S, Chang D, Yang W, Yanigahara D, Koski RA, Yarden Y (1994) Structural and functional aspects of the multiplicity of neu differentiation factors. Mol Cell Biol 14:1909-1919.

Wijsman JH, Jonker RR, Keijzer R, Van De Velde CJH, Cornelisse CJ, Van Dierendonck JH (1993) A new method to detect apoptosis in paraffin sections: in situ end-labeling of fragmented DNA. J Histochem Cytochem 41:7-12.

Yeh HJ, Ruit KG, Wang YX, Parks WC, Snider WD, Deuel TF (1991) PDGF A-chain gene is expressed by mammalian neurons during development and in maturity. Cell 64:209-216. 